\title{
SESEARCHARTICLE FENCED CONSERVATION COMPARED TO LAND EXPOSED TO GRAZING IN DERA GHAZI KHAN (PAKISTAN)
}

\author{
Saeed Ullah", Shamim Umer ${ }^{2 *}$, Muhammad Adnan ${ }^{1}$ \\ ${ }^{1}$ Department of Botany, Ghazi University Dera Ghazi Khan \\ ${ }^{2}$ Department of Botany, University of Agriculture Faisalabad \\ *Corresponding author's E-mail: shameeemnoor111@gmail.com
}

This is an open access article distributed under the Creative Commons Attribution License, which permits unrestricted use, distribution, and reproduction in any medium, provided the original work is properly cited.

\section{ARTICLE DETAILS}

\section{Article History:}

Received 01 August 2019 Accepted 02 October 2019 Available online 09 October 2019

\section{ABSTRACT}

In order to maintain an optimal management method of desert rangelands with high heritage value, there is a need of basic knowledge for the flora of the area under study. For this purpose, sampling was carried out from fenced and un-fenced areas in Dera ghazi khan (Pakistan). Qualitative and quantitative analysis of vegetation were performed. Total number of families and their respective species were recorded. Among quantitative parameters relative frequency and importance value were calculated in the area covered with wire net fence and the open area. Data were analysed statistically. Results showed affected plants species richness as well as soil composition. Fencing proved to be a beneficial management to maintain species diversity. The result indicated significant difference in fenced and unfenced areas. Edaphic factors of both study sites also differed significantly. This difference can be attributed to grazing disturbance, and if managed properly, they can prove a valuable source for livestock with sustainable features.

\section{KEYWORDS}

Fence, soil attributes Species diversity, relative frequency and Importance value, Grazing disturbance, conservation.

\section{INTRODUCTION}

For developing an optimal management method of desert rangelands basic knowledge for the flora of area under study is pre-requisite. Conservation is a careful preservation and protection of planned management of natural resource to prevent exploitation, destruction water and wildlife conservation. Degradation of desert rangeland represents an undesirable change towards decreased sustainability. Thus, ecological restoration and sustainable agriculture in dry lands are the main methods used to preserve their sustainable use and to prevent "desertification" [1].

Our present study is the milestone for such studies to set basic information which would be helpful in managing rangeland in D.G. Khan. The vegetation degradation and soil erosion exacerbated the alkalinity levels in the surface soil, resulting in a severe secondary alkalization process. The vegetation degradation and soil erosion exacerbated the alkalinity levels in the surface soil, resulting in a severe secondary alkalization process. The accumulation of solutes induces primarily alkaline soil processes, with $\mathrm{Na}_{2} \mathrm{CO}_{3}$ and $\mathrm{NaHCO}_{3}$ being the major sources for soil alkalinity. High pH and electrical conductivity are highlighted characteristics for alkaline soil, and these are the principal limiting factors for vegetation establishment in this area $[2,3]$.

Dera Ghazi Khan (D.G. Khan) district is situated between $28^{\circ}-25^{\prime}$ and $31^{\circ}$ $21^{\prime} \mathrm{N}$ latitude $69^{\circ}-20^{\prime}$ and $70^{\circ}{ }_{-} 51^{\prime}$ east longitudes. Summers are hot with temperatures soaring to $45^{\circ} \mathrm{C}$ whereas the winter temperatures are mild and pleasant. Rangelands of the district consist of predominantly plains and Suleiman Hills. Average annual rainfall is about $80 \mathrm{~mm}$. D.G. Khan is one of the relatively underdeveloped areas of Pakistan.

Grazing disturbance has different effects on native and exotic plants, and on various plants functional groups. Therefore, the benefit of fencing may vary in different grasslands and among functional components, such as plants and soil. In recent years, reducing grazing pressure by fencing has been encouraged as an effective way to restore degraded grassland, including the restoration of degraded land and improvement of soil properties in different grassland ecosystems [4-6]. Some researchers concluded from their research that over grazing has two major impacts on grasslands; the livestock grazing reduces vegetation height and changes species composition and cover of grassland communities [7].

Degradation of desert rangeland represents an undesirable change towards decreased sustainability. Despite lower biological production in desert lands, special utilization values of these resources play important roles in their sustainable development. Thus, ecological restoration and sustainable agriculture in dry lands are the main methods used to preserve their sustainable use and to prevent "desertification" [1]. Heavy grazing decreases the occurrence of palatable and mostly perennial species, and it can cause a long-term reduction in the capacity of vegetation to respond to rain, particularly after drought [8].

There is a need to conduct a series of reconnaissance surveys of the D. G. Khan area and to prepare proposal for the development of rangelands with the changing environmental conditions mainly due to anthropogenic involvement. The current work is key to provide the basic knowledge about such projects. The present work at small scale can lead to prove a milestone for the future pilot projects in the area for improvement of rangelands and suppress the deforestation induced by herbivores.

\section{MATERIALS AND METHODS}

Investigation were carried out for the scientific survey of the vegetation of these two areas (fenced and un-fenced or open area) in March 2016.In the study areas, 500 meter transects (East to West) were selected each at the distance of 200 meters; Two transects in the fenced area and two transects in the open area opposite to it. In each transect 10 quadrate areas each of 5 meter square were selected which were 50 meters apart from each other. Among the quantitative tools of vegetation study, presence absence data, relative cover and relative frequency were measured. The sample species in each plot were cut and put into the paper pockets labeled with the locality of its collection along with transect and quadrate number, then transferred to laboratory for further taxonomic identification. 


\subsection{Soil collection}

From each strand, soil samples were collected from the three points (approximately top $10 \mathrm{~cm}$ ) by using trawl and mixed to get a composite sample. The samples were then transferred to polythene bags, labeled and brought to the laboratory for chemical analysis. The soil samples were air dried and then passed through $2 \mathrm{~mm}$ sieve in order to separate gravel and straws from the samples. The soil characteristics studied were $\mathrm{pH}$, electrical conductivity, organic matter, Nitrogen, Potassium, Phosphorus and soil saturation percentage. Frequency, relative frequency, density, relative density, importance value constancy index (IVCI) and importance value were calculated for the all plant species.

Frequency $\%=\frac{\text { Number of quadrats in which species occured }}{\text { Total number of quadrates }} \times 100$

Relative frequency $\%=\frac{\text { Frequency value of a single species }}{\text { Total frequency }} \times 100$

\section{RESULTS AND DISCUSSION}

In the study site, including both fenced and un-fenced area total 32 species belonging to 15 families were observed in the four transacts of 20 quadrates each. These families included Fabaceae, Poaceae, Asteraceae, Zygophyllaceae, Myrtaceae, Solanaceae, Apocynaceae, Euphorbaceae, Amaranthaceae, Rhamnaceae, Meniaspermaceae, Salvodoraceae, Tamaraceae, Cucurbitaceae, Hydrocharitaceae (Table 3 and 4) Among these families fabaceae showed dominance in having $22 \%$ occurrence of its various species. Amaranthaceae comprised of $15 \%$ vegetation of the overall study site Salvodoraceae, Rhamnaceae, Tamaraceae, Zygophyllaceae, Apocynaceae and Cucurbitaceae showed equal score of their presence that is $3 \%$ of each family. In view of life form species, the study site was dominated by herbaceous plants, Vines contributed a little in the site, the life form can be ranked according to their higher percentage of occurrence to lower as:

\section{Herbs $>$ Shrubs $>$ Trees $>$ Vines}

When we compare the floral composition of fenced area, that is protected by anthropogenic disturbance beside grazing with the un-fenced or open area a lot of difference in the frequency and occurrence of plant species is seen table 2. All total twenty-two (32) species observed in the study site were present in the fenced area. Similar views have already been reported stated that heavy grazing affected the diversity of herbs and shrubs [4-6]. However, in un-fenced area that was mark able disturbance by grazing animals. Ten plant species from six families were found in un-fenced area. The families sampled in the open area included Amaranthaceae, Fabaceae, Poaceae, Euphorbaceae, Zygophyllaceae and Solanaceae. Inside the fenced area Withania somnifera dominated, while Desmostachia bipinnata and Alhagi maurorum followed next.

Species such as Fagonia cretica, Withania coagulance,Aerva javanica and Suaeda fruticosa had a considerable frequency in the both fenced and unfenced areas but their frequency was comparatively lesser in open area. Among shrubs plants categories Calotropis procera, Fugonia stipita, Euohorbia milli, Rhyza stricta, Suaeda maritime, Withania coagulance, Ziziphus mauritiana, were present. But their frequency did not exceed more than 22\% Tall trees were lesser in number. Among trees Acacia nilotica, Acacia modesta, Vachellia nilotica, Albizzia lebbeck, were found in the area. Fabaceae dominanated for their canopy of the area.

\subsection{Edophology}

Edophological tests were carried out the laboratory of botany department, Ghazi University D.G Khan. However, the results were also verified by soil and water testing laboratory, D. G Khan as shown in Table 3, 4 and Table 5 after statistical analysis. EC of the soil with fence and un-fenced differ significantly. There is also significant difference in saturation percentage. However, $\mathrm{pH}$ indicated non-significant difference between the two types of samples. EC of the fenced area was found greater than the un-fenced area. Saturation percentage was also greater in fenced area than un-fenced area. Various components of soil samples such as K, P and organic matter indicated significant difference between the samples of two areas.

Table 1: Frequency and Relative frequency of plant species found outside the fenced area.

\begin{tabular}{|l|l|l|l|}
\hline Species & Families & Frequency & $\begin{array}{l}\text { Relative } \\
\text { Frequency }\end{array}$ \\
\hline $\begin{array}{l}\text { Aerva javanica } \\
\text { (Burm.f.) }\end{array}$ & Amaranthaceae & 20 & 8.33 \\
\hline Alhagi maurorum L. & Fabaceae & 30 & 12.5 \\
\hline Cenchrus ciliaris L. & Poaceae & 20 & 8.33 \\
\hline
\end{tabular}

\begin{tabular}{|l|l|l|l|}
\hline $\begin{array}{l}\text { Euphorbia prostrate } \\
\text { L. }\end{array}$ & Euphorbiaceae & 20 & 8.33 \\
\hline Fagonia cretica L. & Zygophylaceae & 30 & 12.5 \\
\hline $\begin{array}{l}\text { Panicum coloratum } \\
\text { Retz. }\end{array}$ & Poaceae & 30 & 12.5 \\
\hline Prosopis cineraria L. & Fabaceae & 30 & 12.5 \\
\hline $\begin{array}{l}\text { Rhazya stricta } \\
\text { Decne. }\end{array}$ & Apocynaceae & 20 & 8.33 \\
\hline Salsola foetida L. & Amaranthaceae & 20 & 8.33 \\
\hline $\begin{array}{l}\text { Withania coagulans } \\
\text { L. }\end{array}$ & Solanaceae & 30 & 12.5 \\
\hline
\end{tabular}

Table 2: Frequency and Relative frequency of plant species found inside the fenced area.

\begin{tabular}{|c|c|c|c|}
\hline Species & Families & Frequency & $\begin{array}{l}\text { Relative } \\
\text { Frequency } \\
\end{array}$ \\
\hline Acacia modesta L. & Fabaceae & 30 & 3.25 \\
\hline Acacia nilotica L. & Fabaceae & 20 & 2.15 \\
\hline $\begin{array}{l}\text { Aerva javanica } \\
\text { (Burm.f.) }\end{array}$ & Amaranthaceae & 30 & 3.25 \\
\hline Albizzia lebbeck L. & Fabaceae & 20 & 2.15 \\
\hline $\begin{array}{l}\text { Alhagi maurorum } \\
\text { L. }\end{array}$ & Fabaceae & 50 & 5.37 \\
\hline $\begin{array}{l}\text { Calotropis procera } \\
\text { L. } \\
\end{array}$ & Apocynaceae & 20 & 2.15 \\
\hline Cenchrus ciliaris $L$. & Asteraceae & 30 & 3.25 \\
\hline $\begin{array}{l}\text { Chenopodium } \\
\text { album L. }\end{array}$ & Amaranthaceae & 20 & 2.15 \\
\hline $\begin{array}{l}\text { Citrulus colosynthis } \\
L \text {. }\end{array}$ & Cucurbitaceae & 20 & 2.15 \\
\hline $\begin{array}{l}\text { Coscinium } \\
\text { fenestratum Gaertn }\end{array}$ & Minispermaceae & 10 & 1.07 \\
\hline $\begin{array}{l}\text { Cyanodon dactylon } \\
L .\end{array}$ & Poaceae & 20 & 2.15 \\
\hline $\begin{array}{l}\text { Desmostachya } \\
\text { bipinnata (L.) Stapf. }\end{array}$ & Poaceae & 60 & 6.45 \\
\hline $\begin{array}{l}\text { Elodea candensis } \\
\text { Michx }\end{array}$ & Hydrocharitaceae & 10 & 1.07 \\
\hline Eugenia stipitata l. & Myrtaceae & 10 & 1.07 \\
\hline Euphorbia milli $L$. & Euphorbiaceae & 30 & 3.25 \\
\hline Fagonia cretica L. & Asteraceae & 50 & 5.37 \\
\hline $\begin{array}{l}\text { Panicum coloratum } \\
\text { Retz. }\end{array}$ & Poaceae & 30 & 3.25 \\
\hline Peganum hermalla & Zygophylaceae & 30 & 3.25 \\
\hline $\begin{array}{l}\text { Prosopis cineraria } \\
\text { L. }\end{array}$ & Fabaceae & 20 & 2.15 \\
\hline $\begin{array}{l}\text { Rhazya stricta } \\
\text { Decne }\end{array}$ & Fabaceae & 50 & 5.37 \\
\hline Salsola foetida l. & Amaranthaceae & 30 & 3.25 \\
\hline $\begin{array}{l}\text { Salvadora oleoides } \\
\text { L. }\end{array}$ & Salvadoraceae & 10 & 1.07 \\
\hline $\begin{array}{l}\text { Sonchus arvensis } \\
\text { (L.)Hill. }\end{array}$ & Asteraceae & 50 & 5.37 \\
\hline Suaeda fruticosa $L$. & Amaranthaceae & 60 & 6.45 \\
\hline Suaeda maritime L. & Amaranthaceae & 20 & 2.15 \\
\hline Tamarix aphylla $L$. & Tamaraceae & 10 & 1.07 \\
\hline $\begin{array}{l}\text { Tribulus terrestris } \\
\text { L. }\end{array}$ & Zygophylaceae & 10 & 1.07 \\
\hline Vachellia nilotica L. & Ericaceae & 10 & 1.07 \\
\hline $\begin{array}{l}\text { Withania coagulans } \\
\text { L. }\end{array}$ & Solanaceae & 60 & 6.45 \\
\hline $\begin{array}{l}\text { Withania somnifera } \\
\text { L. }\end{array}$ & Solanaceae & 70 & 7.52 \\
\hline $\begin{array}{l}\text { Ziziphus } \\
\text { mauritiana } \\
\text { (Burm.f.) }\end{array}$ & Rhamnaceae & 30 & 3.25 \\
\hline
\end{tabular}


Table 3: Analysis of Variance for estimation of EC of soil samples collected from two localities (Fenced Area and Un-fenced area).

\begin{tabular}{|c|c|c|c|c|c|}
\hline Source & DF & SS & MS & F. Value & P. Value \\
\hline $\begin{array}{c}\text { Treatment } \\
\text { (Localities) }\end{array}$ & 01 & 1.80601 & 1.80601 & 15.46 & 0.0010 \\
\hline Error & 18 & 2.31029 & 0.11685 & & \\
\hline Total & 19 & 3.90930 & & & \\
\hline
\end{tabular}

Table 4: Analysis of Variance for estimation of Organic matter of soil samples collected from two localities (Fenced Area and Un-fenced area).

\begin{tabular}{|c|c|c|c|c|c|}
\hline Source & DF & SS & MS & F. Value & P. Value \\
\hline Treatment & 1 & 0.22685 & 0.22685 & 19.28 & 0.0004 \\
\hline Error & 18 & 0.21181 & 0.01177 & & \\
\hline Total & 19 & 0.43866 & & & \\
\hline
\end{tabular}

Table 5: Analysis of Variance for estimation of Soil pH content in two localities i.e fenced Area and excluded area.

\begin{tabular}{|c|c|c|c|c|c|}
\hline Source & DF & SS & MS & F. Value & P. Value \\
\hline Treatment & 01 & 0.05000 & 0.05000 & 6.08 & 0.239 \\
\hline Error & 18 & 0.14800 & 0.00822 & & \\
\hline Total & 19 & 0.19800 & & & \\
\hline
\end{tabular}

\section{CONCLUSIONS}

The structure, richness and composition of vegetation are considerably affected by livestock grazing. We found a protected area covered by a fence since last ten years and studied the effects of grazing on floral composition. Results indicate the affected plant species richness as well as soil composition. Fencing proved to be a beneficial management to maintain species diversity. Properly managed rangelands provide main feed resource the system of livestock management. Overgrazing is the cause of the desert rangelands becoming degraded. Heavy consumption of palatable plant species under grazing proved to be a potential mechanism for reduced frequency and species composition. In our study, it was also been that some non- palatable species also disappeared from the unfenced area. It is thought that this happened due to mechanical disturbance on plants species as well as due to animals. The fenced area plays an important role for the protection of biodiversity of plants species.

\section{REFERENCES}

[1] Reynolds, J.F., Smith, D.M.S., Lambin, E.F. 2007. Global desertification: building a science for dryland development. Sci., 316, 847-851.

[2] Gao, Q., Yang, X.S., Yun, R. 1996. Mage, a dynamic model of alkaline grassland ecosystems with variable soil characteristics. Ecol. Mod., 93, 1932.

[3] Jiang, S.C., He, N.P., Wu, L. 2010. Vegetation restoration of secondary bare saline-alkali patches in the Songnen plain, China. Appl. Vegetation Sci., 13, 47-55.

[4] Pei, S.F., Fu, H., Wan, C.G. 2008. Changes in soil properties and vegetation following exclosure and grazing in degraded Alxa desert steppe of Inner Mongolia, China. Agric. Eco. Environ., 124, 33-39.

[5] Wu, G.L., Du, G.Z., Liu, Z.H. 2009. Effect of fencing and grazing on a Kobresia-dominated meadow in the Qinghai-Tibetan Plateau. Plant and Soil, 319, 115-126.

[6] Shang, Z.H., Deng, B., Ding, L.M. 2013. The effects of three years of fencing enclosure on soil seed banks and the relationship with aboveground vegetation of degraded alpine grasslands of the Tibetan plateau. Plant and Soil, 364, 229-244.

[7] Su, Y., Li, Z.Y.L., Cui, J.Y. 2005. Influences of continuous grazing and Sudanian zone. J. Range Management, 30, 181-189.

[8] Kinloch, J.E., Friedel, M.H. 2005. Soil seed reserves in arid grazing lands of central Australia. Part 1: seed bank and vegetation dynamics. 